\title{
Seasonal Variation in Thyroid Hormones and Reproduction in the Egyptian Water Buffalo
}

\author{
A.M.A. Borady* A.E. Abdelaal** and H.AM. Farghaly** \\ *Department of Animal Production, Faculty of Agriculture, \\ Cairo University, Giza, Egypt. \\ ** Department of Radiobiology, Nuclear Research center, \\ Atomic Energy Authority, Cairo, Egypt.
}

14 CYCLING buffaloes ( 7 heifers and 7 cows) were used in the 14 present investigation to study the pattern of changes in the concentration of serum triiodothyronine (T-3) and total thyroxine (T-4) due to the season of the year. Relationship between the level of thyroid hormones $\left(T_{3} \& T_{4}\right)$ and ovarian activity was also studied.

The overall mean of $T_{3}$ and $T_{4}$ in serum of buffalo heifers and cows was $88.2 \mathrm{ng} \%$ and $3.1 \mathrm{ug} \%$ respectively. These values were affected by the season of the year. The concentrations of both hormones were $87.1 \mathrm{ng} \mathrm{\&} 3.00 \mathrm{ug} \%$ in autumn; 119.1 \& $4.31 \mathrm{in}$ winter; $93.5 \& 3.13$ in spring and $73.2 \& 2.76$ in summe respectively. These fluctuations in $T_{3}$ and $T_{1}$ levels were greately issociated with the changes in the ovarian activity during the four seasons of the year. The increase in $T_{4}$ concentration during autumn and winter was accompanied with decreased percent of silent heats reduced ovarian cycles and high incidense of silent heat were observed during summer, where $T_{3}$ and $T_{4}$ were at their minimal levels.

The thyroid gland has long been implicated in the control of estrus and maintenance of pregnancy in several species including human. Earlier studies have shown that, thyroid activity and fertility in the Egyptian buffaloes are reduced in hot weather (Afiefy, 1966; Kamal and Ibrahim, 1969 ; El-Fouly et al. 1976 ; Borady et al. 1982 and El-Shafie et al., 1983).

The present investigation was undertaken to study the effect of season on the level of thyroid hormones and the reproductive status of buffalo heifers and cows.

\section{Material and Methods}

Experiments of the present study were carried out on two groups (seven each) of cycling buffalo heifers (approximately two years old) and cows (more than three years old), belonging to the Animal physiology Research Laboratory, Department of Animal production, Faculty of Agriculture, Cairo University. The animals were free from any major illness and chronic diseases, and were housed in an open shed. They were fed according to their live weight and 
milk production (lactating cows). During winter and spring seasons (December, through April) the animals were offered concentrate ration, Egyptian clover (Trifolium Alexandrinum) and rice straw. The concentrate ration contained $16 \%$ crude protein, $2 \%$ fat and $16.5 \%$ crude fibers. During summer and autumn seasons (May through November) concentrates and rice straw were provided. Green fodder was offered whenever available.

Field observations were carried out over one year period. The animals were checked for heat symptoms three times daily (at 9:00 am, 2:00 and $7: 00 \mathrm{pm}$ ) using two approned fertile males. Three symptoms were observed ; i) receptivity to the male ; ii) pre-amounting grunt and iii) vaginal discharge. Rectal palpation was done once a week.

Blood samples were collected at weekly intervals and on estrus day for one year. Serum was separated and stored at 20-C until analysed, for triiodothronine (T-3) (Chopra, 1972) and total thyroxine (T-4) radio immunoassay (Larsen, 1972). Anti T-3 and T-4 were obtained from Diagnostics Biochem. Canada, Inc., London, Ontario, Canada. Radioactive iodine (I-125: IMS-30) was obtained from Amersham Co. England. I-125 T-3 and I-125 $\mathrm{T}-4$ were prepared in our laboratories using the Chloramine $\mathrm{T}$ method. Column chromatography was carried out using sephadex G-25 fine (Pharmacia, Upsala, Sweden), equilibrated with phosphate buffer at a PH of 11.6 (Ibrahim et al., 1982).

The data obtained were evaluated using the analysis of variance and Duncan's Multiple range "t"' test (Steel \& Torrie, 1960).

\section{Results and Discussion}

The results obtained in this study have clearly demonstrated the seasonal variation in the level of T-3 and T-4 in the sera of buffaloes. Table 1 shows the monthly mean values of both hormones in heifers and cows, as well as, the combined results for both. Generally speaking, the levels were high during cold months and low during the hot ones. Transitional levels were noted during the months of moderate weather. The pooled date (of both beifers and cows) showed that the concentration of both hormones were decreased gradulally from $1023 \mathrm{ng} \%$ and $3.14 \mathrm{ug} \%$ (for T-3 and T-4 respectively) in April to a minimal level of $71.2 \mathrm{ng} \%$ and $2.68 \mathrm{ug} \%$ (for $\mathrm{T}-3$ and $\mathrm{T}-4$, respectively) in June. This minimal level was followed by slight increase from July up to October, then a noticeable increase took place in November to reach maximal value in February. The declining pattern started in March (Table 1) Such pattern of change in thyroid activity in Egyptian buffaloes was observed by Afiey (1966). Both results indicate that the. thyroid activity is changed before the animal is subjected to the following different seasonal factors.

Egypt. J. Anim. Prod. 25, No. 1 (1985) 
Table 2 shows the mean values for $T-3$ and $T-4$ during the four seasons of the year (Winter : Dec. - Feb., Spring : March - May, Summer * June Aug. and Autumn : Sept. - Nov.). The lowest levels of both hormones were observed during summer, while winter was characterized by the highest values. The analysis of variance showed significant differences between the four seasons of the year $(\mathrm{p}<0.01)$. Further statistical evaluation (using Duncan's multiple range " $t$ " test) indicated that the differences between the values in winter were significant, when compared to those noticed in summer, spring and autumn. The later tow seasons were almost similar in T-3 and T-4 levels, but both of them were significantly higher than summer $(p<0.01)$. Afiefy $(1966)$, kamal and Ibrahim (1969), also stated such seasonal variation in thyroid activity in Egyptian buffaloes.

TABLE 1. Monthly mean values for $\mathrm{T}-4(\mathrm{ug} \%)$ and $\mathrm{T}-3(\mathrm{ng} \%)$ in serum of buffalo heifers and cows during one year.

\begin{tabular}{|c|c|c|c|c|c|c|}
\hline \multirow[t]{2}{*}{ Month } & \multicolumn{2}{|c|}{ Buffalo heifers } & \multicolumn{2}{|c|}{ Buffalo cows } & \multicolumn{2}{|c|}{$\begin{array}{l}\text { Buffalo heifers } \\
\text { cows }\end{array}$} \\
\hline & $T-4$ & $T-3$ & T-4 & $\mathrm{T}-3$ & $\mathrm{~T}-4$ & T-3 \\
\hline Jan. ... & $\begin{aligned} & 4.71^{*} \\
\pm & 0.3\end{aligned}$ & $\begin{array}{r}151.4 \\
\pm 9.0\end{array}$ & $\begin{aligned} & 4.16 \\
\pm & 0.2\end{aligned}$ & $\begin{array}{r}121.9 \\
\pm 11.2\end{array}$ & $\begin{aligned} & 4.38 \\
\pm & 0.2\end{aligned}$ & $\begin{array}{l}133.7 \\
\pm 8.1\end{array}$ \\
\hline Feb. ... & $\begin{aligned} & 4.94 \\
+ & 0.4\end{aligned}$ & $\begin{array}{l}131.6 \\
\pm 6.2\end{array}$ & $\begin{aligned} & 4.95 \\
\pm & 0.4\end{aligned}$ & $\begin{array}{r}147.8 \\
\pm 29.6\end{array}$ & $\begin{array}{ll} & 4.94 \\
\pm & 0.3\end{array}$ & $\begin{array}{r}138.8 \\
\pm 12.8\end{array}$ \\
\hline March . . & $\begin{aligned} & 3.33 \\
\pm & 0.1\end{aligned}$ & $\begin{array}{r}98.0 \\
\pm 6.0\end{array}$ & 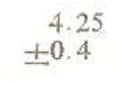 & $\begin{array}{r}95.8 \\
\pm 11.3\end{array}$ & $\begin{aligned} & 3.53 \\
\pm & 0.1\end{aligned}$ & $\begin{array}{r}97.5 \\
\pm 5.2\end{array}$ \\
\hline April . . & $\begin{aligned} & 2.96 \\
\pm & 0.1\end{aligned}$ & $\begin{array}{r}98.4 \\
\pm 6.0\end{array}$ & $\begin{aligned} & 3.53 \\
\pm & 0.3\end{aligned}$ & $\begin{array}{l}110.8 \\
\pm 9.5\end{array}$ & $\begin{aligned} & 3.14 \\
\pm & 0.1\end{aligned}$ & $\begin{array}{r}102.3 \\
\pm 5.1\end{array}$ \\
\hline May ... & $\begin{aligned} & 2.80 \\
\pm & 0.1\end{aligned}$ & $\begin{array}{r}78.3 \\
+4.5 \\
\end{array}$ & $\begin{aligned} & 2.99 \\
\pm & 0.1\end{aligned}$ & $\begin{array}{r}93.8 \\
\pm 5.4\end{array}$ & $\begin{aligned} & 2.87 \\
\pm & 0.1\end{aligned}$ & $\begin{array}{r}85.5 \\
\pm 3.6\end{array}$ \\
\hline June ... & $\begin{aligned} & 2.55 \\
\pm & 0.1\end{aligned}$ & $\begin{array}{r}67.8 \\
\pm 4.1 \\
\end{array}$ & $\begin{aligned} & 2.79 \\
\pm & 0.1\end{aligned}$ & $\begin{array}{r}74.5 \\
+5.5\end{array}$ & $\begin{aligned} & 2.68 \\
+ & 0.1\end{aligned}$ & $\begin{array}{r}71.2 \\
\pm 3.5 \\
\end{array}$ \\
\hline July , . . & $\begin{aligned} & 2.76 \\
\pm & 0.1\end{aligned}$ & $\begin{array}{r}68.6 \\
\pm 5.6\end{array}$ & $\begin{aligned} & 2.90 \\
\pm & 0.1\end{aligned}$ & $\begin{array}{r}79.4 \\
\pm 6.7\end{array}$ & $\begin{aligned} & 2.83 \\
+ & 0.1\end{aligned}$ & $\begin{array}{r}74.3 \\
\pm 4.4\end{array}$ \\
\hline Aug. . . & $\begin{aligned} & 2.85 \\
\pm & 0.1\end{aligned}$ & $\begin{array}{r}70.9 \\
\pm 4.0\end{array}$ & 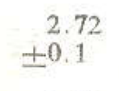 & $\begin{array}{r}74.0 \\
+3.5\end{array}$ & $\begin{aligned} & 2.77 \\
\pm & 0.1\end{aligned}$ & $\begin{array}{r}73.9 \\
\pm 3.4 \\
\end{array}$ \\
\hline Sept. . . & $\begin{aligned} & 2.87 \\
+ & 0.1\end{aligned}$ & $\begin{array}{r}72.4 \\
\pm 4.0\end{array}$ & $\begin{aligned} & 2.80 \\
&+ 0.2 \\
&\end{aligned}$ & $\begin{array}{r}81.3 \\
\pm 5.1\end{array}$ & $\begin{aligned} & 2.83 \\
\pm & 0.1\end{aligned}$ & $\begin{array}{r}77.7 \\
\pm 3.5\end{array}$ \\
\hline Oct. ... & $\begin{aligned} & 2.84 \\
\pm & 0.2\end{aligned}$ & $\begin{array}{r}76.6 \\
\pm 6.0\end{array}$ & $\begin{array}{ll} & 2.85 \\
\pm & 0.1\end{array}$ & $\begin{array}{r}85.2 \\
\pm 4.6\end{array}$ & $\begin{aligned} & 2.85 \\
\pm & 0.1\end{aligned}$ & $\begin{array}{r}82.3 \\
+3.7\end{array}$ \\
\hline Nov... . & $\begin{aligned} & 3.25 \\
\pm & 0.2\end{aligned}$ & $\begin{array}{r}93.2 \\
\pm 11.9\end{array}$ & $\begin{aligned} & 3.48 \\
\pm & 0.1\end{aligned}$ & $\begin{array}{l}111.2 \\
\pm 7.8\end{array}$ & $\begin{aligned} & 3.39 \\
\pm & 0.1\end{aligned}$ & $\begin{array}{r}104.3 \\
\pm 6.6\end{array}$ \\
\hline Dec. . . . & $\begin{array}{ll} & 3.67 \\
\pm & 0.2 \\
\end{array}$ & $\begin{array}{r}86.8 \\
\pm 7.5 \\
\end{array}$ & $\begin{array}{r}4.3 \\
\pm 0.3 \\
\end{array}$ & $\begin{array}{r}109.5 \\
\pm 11.0 \\
\end{array}$ & $\begin{array}{r}4.05 \\
\pm 0.2 \\
\end{array}$ & $\begin{array}{r}100.4 \\
\pm 7.5 \\
\end{array}$ \\
\hline
\end{tabular}

* Results expressed as mean $\pm \mathrm{SE}$.

Egypt. J. Anim. Prod. 25, No. 1 (1985) 


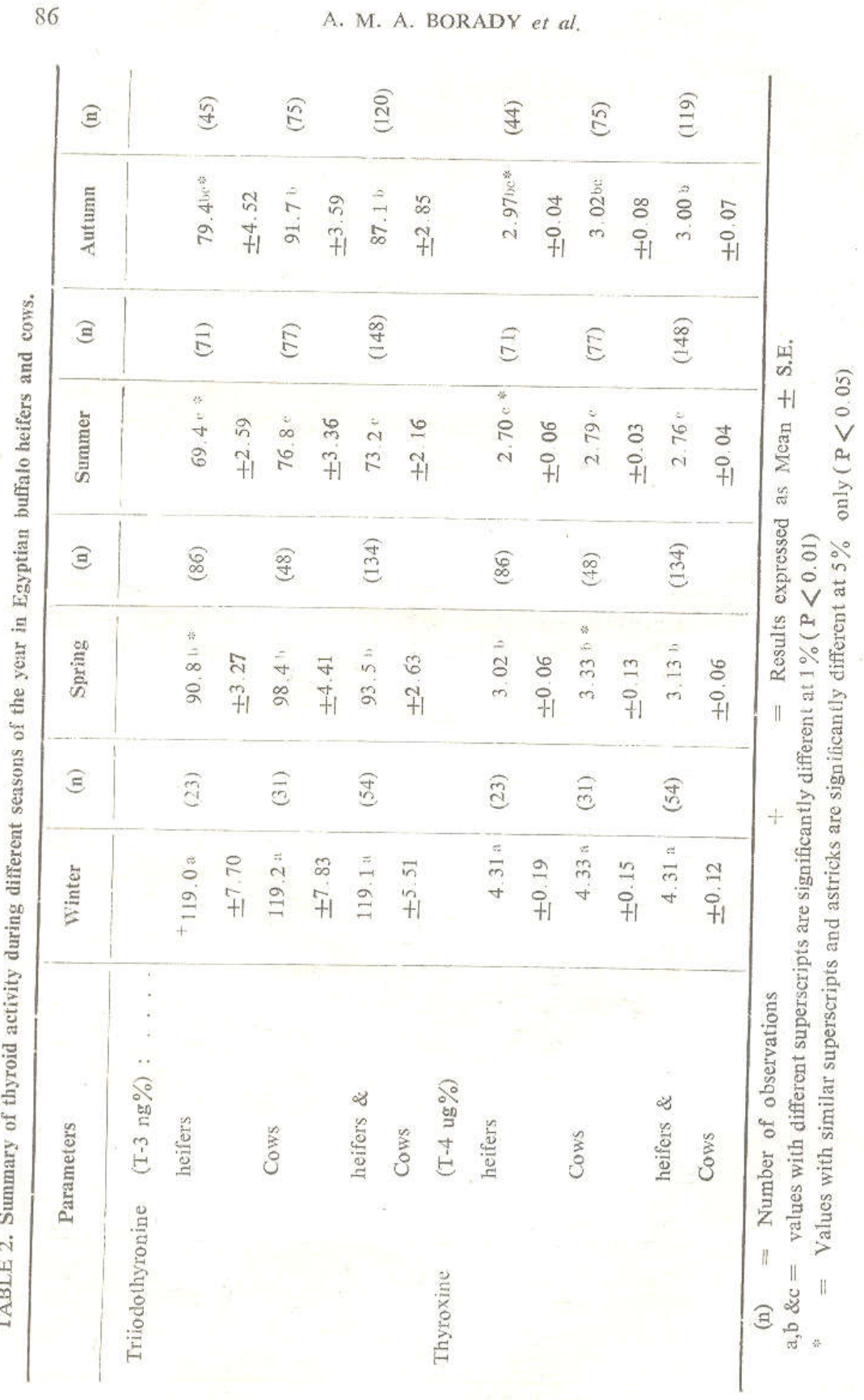

Egypt. J. Anim. Prod. 25, No. 1 (1985) 


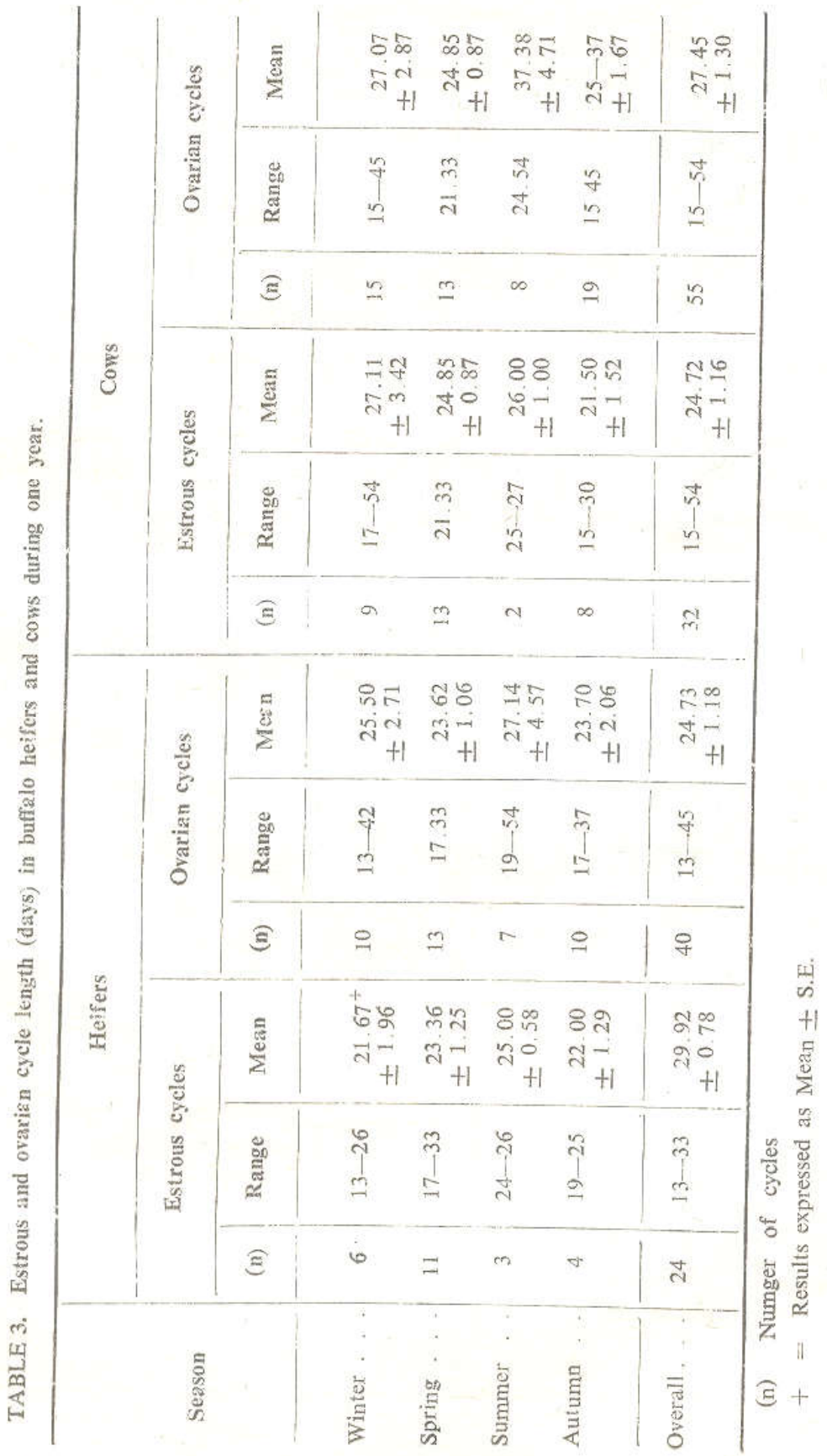

Egypt. J. Anim. Prod. 25, No. 1 (1985) 
The season of the year influenced the manifestation of estrus, the length of the cycle and the activity of the ovaries in both buffalo heifers and cows (Tables $3 \& 4$ ). The highest incidence of heat was observed during spring months, being $38.9 \%$ in heifers and $34.1 \%$ in cows. Hot months, especially July and August, were characterized by reduced ovarian activity and consequently less cycles ( 3 out of 24 and 2 out of 32 cycles in heifers and cows respectively (Table 4). Also, whenever the ovaries becane active in summer, high incidence of quite ovulation (61.1\% of ovulations) was recorded (Table 4).

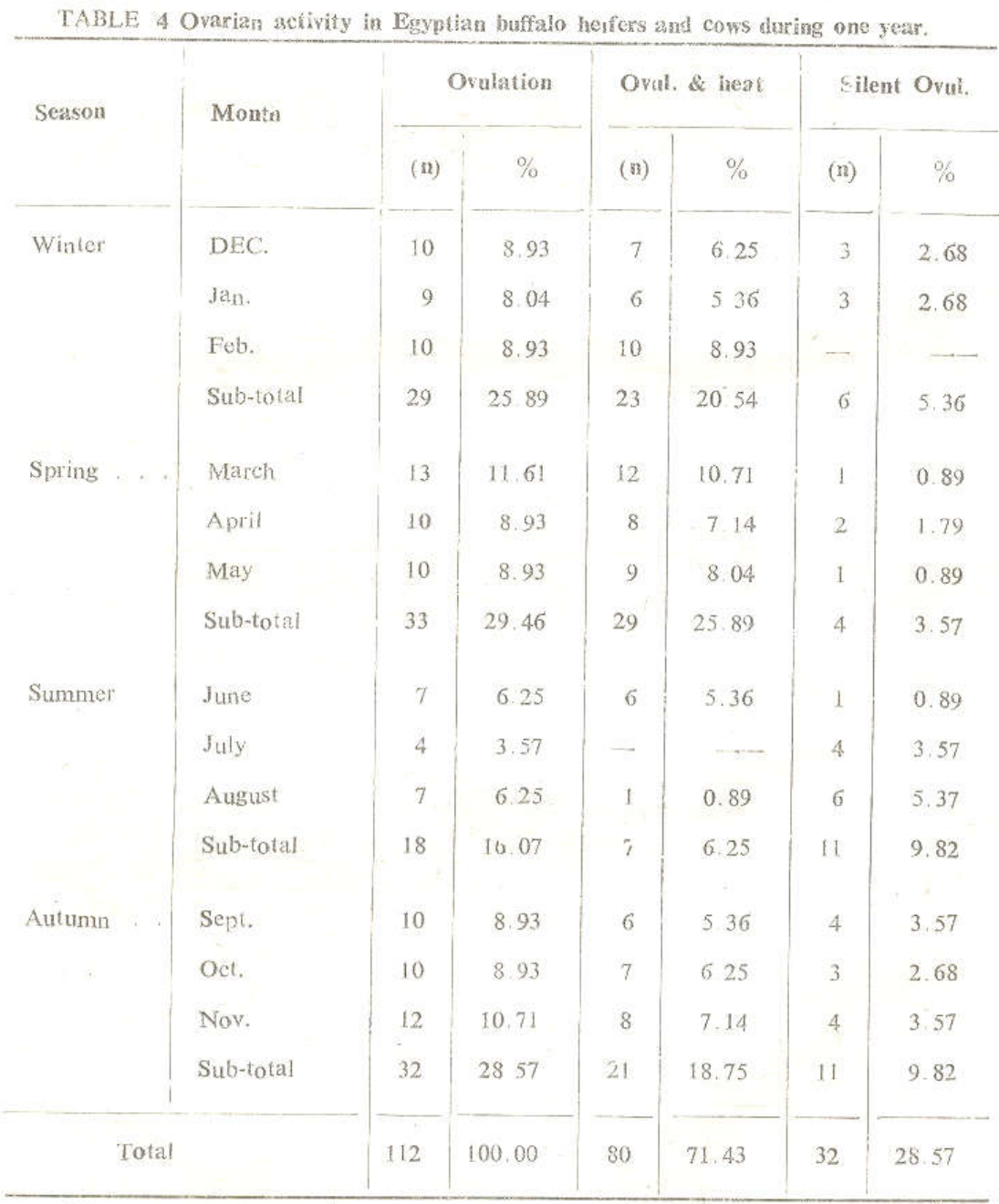

(n) = Number of cases observed.

$\% \quad=$ Percent of total ovulations detected.

Egypt. J. Anim. Prod. 25, No. 1 (1985) 
The response of ovaries to different seasonal factors was not the same in buffalo heifers and cows. In heifers, long ovarian cycles of $33-42$ days were more frequent $(30 \%)$ during winter, while in cows $75 \%$ of the cycles observed in summer were long (27-54 days). El-Sheikh and El-Fouly (1971) also found that the length of ovulatory cycles in buffalo heifers was significantly longer durind winter, as compared to the other seasons. In cows, the incidence of long ovarian cycles was more frequent in summer (Mohamed, 1974). The major factor responsible for long ovarian cycles has been attributed to the persistence of corpus luteum (El-Nouty, 1971 ; Mohamed, 1974 and khattab, 1980). Most Egyptian investigators believe that summer ovarian inactivity in buffaloes is due to high environmantal temperature, long day length and lack of green fodder (Hafez, 1955; Afiefy, 1966).

From the results of the present study, maximal activity of heifer's ovaries were during winter and spring while in cows autumn, winter and spring seasons were the seasons of high ovarian activity (Tables $3 \& 4$ ). El-Fouly et al., (1976) also found increased ovarian activity during winter and spring (Oct. March). They refer this difference to decreased daylight and lowered air temperature,

Assessment to the relationship between the level of the thyroid hormones and ovarian activity was carried out on the data obtained, regardless of the season of the year. Analysis of variance for the concentrations of T-3 and T-4 revealed significant differences in the level of thyroid hormones during the different reproductive stages in heifers and cows $(p<0.01)$. Duncan's multiple " $t$ " test showed that the level of both $\mathrm{T}-3$ and $\mathrm{T}-4$ during cycles without heat signs (silent heat) was significantly lower $(\mathrm{T}-3=72 \cdot 1,81 \cdot 1 \mathrm{ng} \%$ and $\mathrm{T}-4=2.68,2.83 \mathrm{ug} \%$ than on estrus days $(\mathrm{T}-3=106.3,108.4 \mathrm{ng} \%$ and $\mathrm{T}-4=3.70,3.87 \mathrm{ug} \%$ ) and during estrous cycles (T-3 $=100.0,97.6 \mathrm{ng} \%$ and $\mathrm{T}-4=3 \cdot 20,3.60 \mathrm{ug} \%$ ) in buffalo heifers and cows, respectively (Table 5).

The pattern of ovarian activity during the four seasons of the year seems to be associated with the fluctuations in T-3 and T-4 levels (see Tables 1, 2 and 4) The increase in T-4 concentration from $3.00 \mathrm{ug} \%$ during autumn to $4.31 \mathrm{ug} \%$ during winter was associated with decreased percentage of silent heats (from $9.82 \%$ in autumn to $5.36 \%$ in winter). On the other hand, when T-3 and $\mathrm{T}-4$ concentrations were low during summer $(\mathrm{T}-3=73.2$ and $\mathrm{T}-4=2.76)$ the incidence of silent heat was increased (11 out of 18). Therefore, it scems that thyroid hormones play a role in ovarian activity and the manifestation of estrus. However, Benjaminsen (1981) was not able to detect any significant differences in T-4 levels between cows with silent heat and those with overt estrus. In dairy cattle, Andersen et al., (1980) did not notice any differences in either serum total thyroxine or free thyroxine index between cows showing strong estrus and those with weak/silent heat. They suggested that a minimum level of T-4 $(1 \cdot 54-2 \cdot 31$ ug \& $\&$ is necessary for the cow to come into heat and that the sensitivity to thyroxine level perse may vary between cows. The contradiction between our results and those of Benjaminsen, (1981)and Andersen et al., (1980) may be due to species differences.

Egypt. J. Anim. Prod. 25, No. 1 (1985) 
A.M.A, BORADY et al.

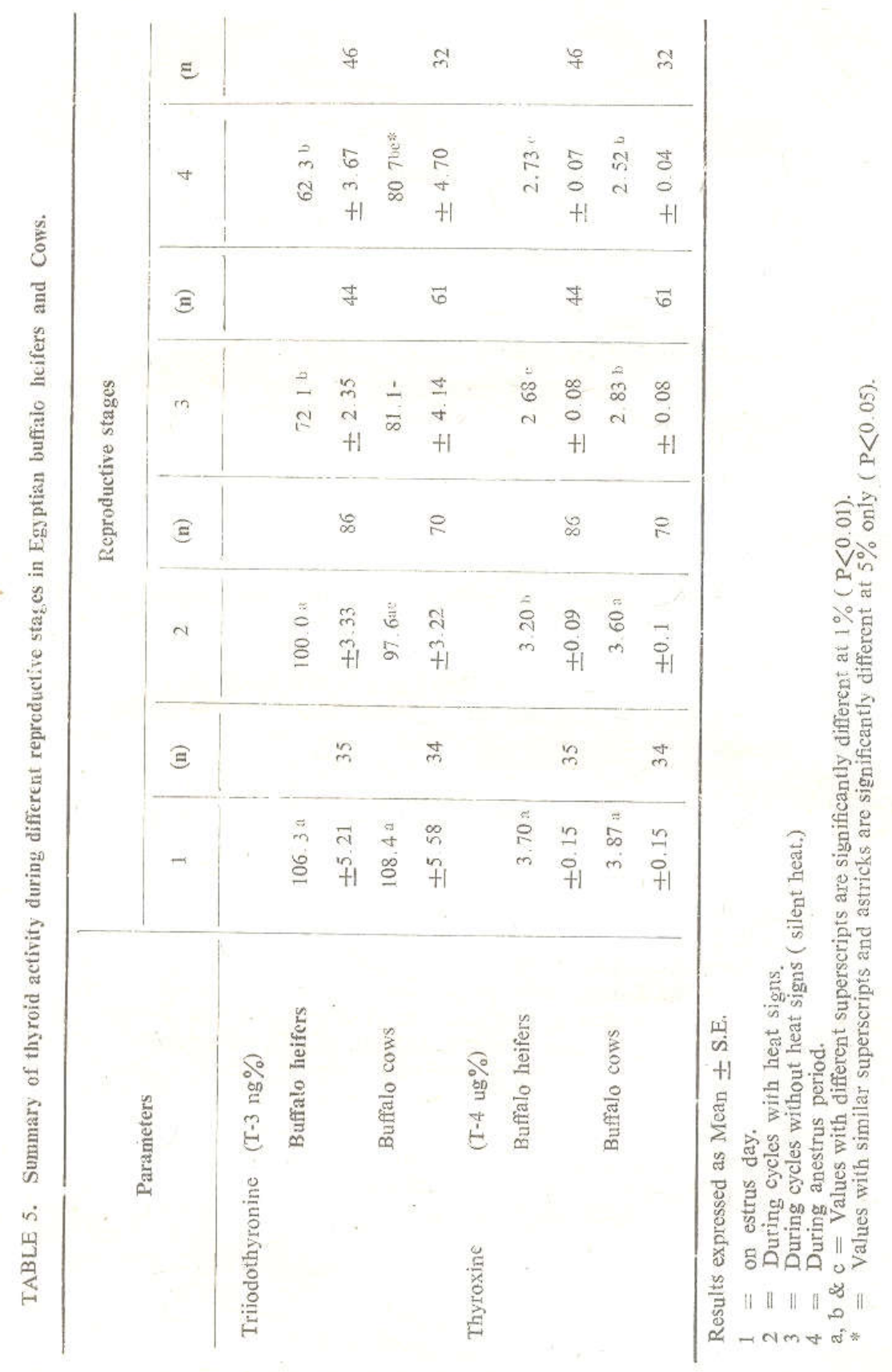

Egvpt. J. Anim. Prod. 25, No. 1 (1985) 


\section{References}

Afiefy, M.M. (1966) Seasonal variations in thyroxine and iodine contents in relation to fertility in Buffaloes and cattle.M.D. Vet. Thesis, Fac. of Vet. Med.,Cairo Univ.

Andresen, $\varnothing$, J., Amrud, L.E. Grholt, G. Helland, E.A. Schie and Syllias G.A. (1980). Total thyroxine and free thyroxine index in plasma of dairy cows in relation to strengti of heat. Acta. Vet. Scand., $21: 108-112$.

Benjaminsen, E. (1981). Plasma thyroxine in the sow during pregnancy and lactation and during resumption of ovarian activity after weaning. Acta. Vet. Scand, 22:369 - 381

Borady, A.M.A.; Morad; H.M. El-Shafie; M.M., Bedeir L.H and Khattab R.H. (1982) Seasonal variations in the reproductive activity of Egyptian Buffaloes 6 th Int Conf on Animal and Poultry Production, Zagazig, Sept, 21-23, 1982, pp. 210-230

Chopra, I.J. (1972). A radioimmunoassay for measurement of thytoxine in unextracted serum J. Clin. Endocr. Metab., 34: $938-947$

El-Fouly, M.A.; Kotby E.A. and Ed-Sobhy H.E. (1976) The functional reproductive peak in Egyptian Buffalo Cow related to day length and ambient temperature Archivio Veterninario Italiano, 27:123-129

El-Nouty, F.E. (1971) The effect of different feeding systems before and after weaning on age at puberly and age at first conception in buffalo heifers M Sc Thesis, Fac of Agric., Ain Shams Univ., Cairo.

EI - Shafie, M.M, Borady, A.M.A., Mourad H.M. and Khattab, R.M. (1983). Physiological and seasodal factors affecting reproductive performance of Egyptian Buffalo heifers. J. Anim prod. Egypt., 23, 1-14.

El - Sheikh, A.S. and El - Foulq M.A. (1977). Ovulation stucies in a herd of buffalo heifers. Alex J, Agric Res, 19: 159-163

Hafez, E.S.P. (1955) Puberty in the buffalo cow. J. Agric. Sci. Camb., $46: 137-142$.

Ibrahim, I.I., Glyda A. and Kosowciz J. (1982). Thyroid hormones in human breast milk. Endocrinol. Polska, $33: 71-77$.

Kamal, T.H. and Ibrahim I.I. (1969) The effect of the natural climate of the Sahara and controlled climate on thyroid gland activity in Friesian cattle and Water Buffaloes. Int. J. Biometeor., 13 ( $3 \&$ 4) : $287-294$.

Khattab, R.M. (1980). Study of some reproductive performance of Egyptian buffalo heifers. M. Sc. Thesis. Fac. of Agric., Cairo Univ., Egypt.

Larsen, P.R. (1972). Direct immunoassay of triiodothyronine in human serum. $J$ Clin. Invest., $51,1939-1949$.

Mohamed, A.A. (1974). Physiological changes in teh reproductive organs of buffloes from parturition to conception. $p h$. D. Thests, Fac. of Agric., Al-Azhar Univ.,Egypt

Steel, R.G.D. and Torrie J.H. (1960), Principles and Procedures of statistics. Mc
Graw- Hill Book Co., New York. 


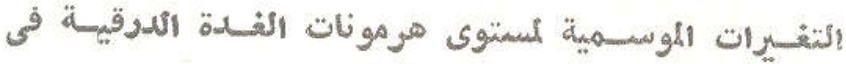

$$
\begin{aligned}
& \text { : }
\end{aligned}
$$

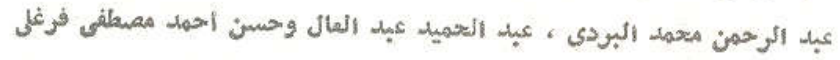

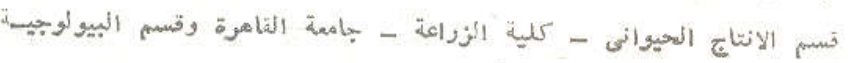

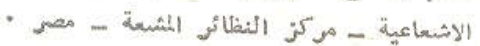

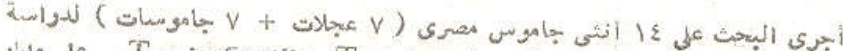

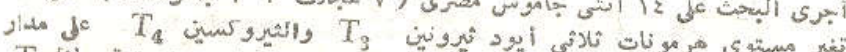

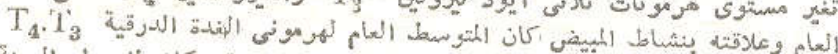

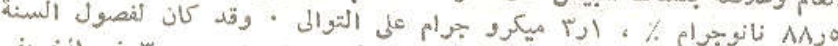

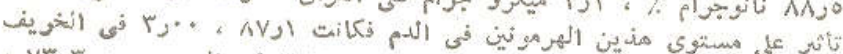

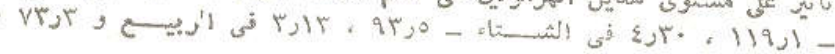

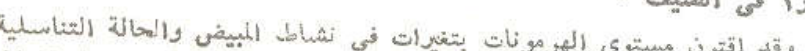

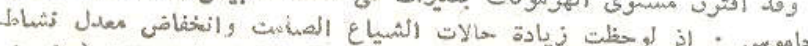

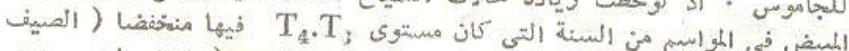

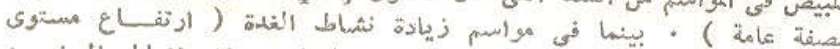

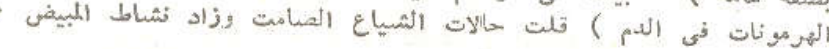

Egypt. J. Anim. Prod. 25, No. 1 (1985) 